\title{
A Comparative Study of the Growth and Nutrient Removal Effects of Five Green Microalgae in Simulated Domestic Sewage
}

\author{
$\mathrm{Li} \mathrm{Ji}^{1}$, Qili Ge ${ }^{1}$, Yuan $\mathrm{Li}^{1}{ }^{1}$, Yifan Gao ${ }^{2}$ (I) and Shulian $\mathrm{Xie}^{3, *(\mathbb{D}}$ \\ 1 School of Environmental Science and Engineering, Taiyuan University of Science and Technology, \\ Taiyuan 030024, China; jili@tyust.edu.cn (L.J.); S20190691@stu.tyust.edu.cn (Q.G.); \\ liyuan_198711@sina.com (Y.L.) \\ 2 School of Chemical and Biological Engineering, Taiyuan University of Science and Technology, \\ Taiyuan 030021, China; gaoyifan@tyust.edu.cn \\ 3 Shanxi Key Laboratory for Research and Development of Regional Plants, School of Life Science, \\ Shanxi University, Taiyuan 030006, China \\ * Correspondence: xiesl@sxu.edu.cn
}

check for updates

Citation: Ji, L.; Ge, Q.; Li, Y.; Gao, Y.; Xie, S. A Comparative Study of the Growth and Nutrient Removal Effects of Five Green Microalgae in Simulated Domestic Sewage. Water 2021, 13, 3613. https://doi.org/ 10.3390/w13243613

Academic Editor: Ignacio de Godos

Received: 3 November 2021

Accepted: 9 December 2021

Published: 16 December 2021

Publisher's Note: MDPI stays neutral with regard to jurisdictional claims in published maps and institutional affiliations.

Copyright: (c) 2021 by the authors. Licensee MDPI, Basel, Switzerland. This article is an open access article distributed under the terms and conditions of the Creative Commons Attribution (CC BY) license (https:/ / creativecommons.org/licenses/by/ $4.0 /)$.

\begin{abstract}
Microalgae have shown great potential in wastewater treatment. This study evaluates the growth and nutrient removal characteristics of five different microalgae strains, namely Chlorella vulgaris, Tetradesmus obliquus, Parachlorella kessleri, Hydrodictyon sp., and Scenedesmus quadricauda, in simulated domestic wastewater. The five microalgae could adapt to wastewater, but the growth potential and nitrogen removal capacity were species dependent. The nutrient removal effect of the microalgae used in this experiment was about $50 \%$ in the first two days. Parachlorella kessleri, selected from the five strains of green algae, shows good potential in removing nutrients from simulated domestic wastewater. For the simulated domestic sewage treated with Parachlorella kessleri, the chemical oxygen demand was almost completely reduced, and ammonium- $\mathrm{N}\left(\mathrm{NH}_{4}-\mathrm{N}\right)$ and total nitrogen (TN) removal exceeded $70 \%$ at the end of the 10-day treatment. Total phosphorus (TP) removal was slightly worse, more than $65 \%$. Parachlorella kessleri showed the best growth in sewage with the highest biomass reaching $366.67 \mathrm{mg} \mathrm{L}^{-1}$ and the highest specific growth rate reaching $0.538 \mathrm{~d}^{-1}$. This study can provide a reference for selecting suitable microalgae species to treat actual domestic sewage.
\end{abstract}

Keywords: green algae; growth characteristics; nutrient removal; simulated domestic sewage

\section{Introduction}

Rapid urbanization brings a significant amount of wastewater emission and generates more environmental risks [1-3]. Domestic sewage is one of the main sources of water pollution, as it can easily cause the eutrophication of water bodies [4], and has aroused great public concern in recent years $[2,5]$. Domestic sewage is rich in organic matter and nutrients, and it is derived from various scattered sources [6]. The discharge of domestic sewage generated by human activities in urban and rural areas can directly or indirectly result in the serious pollution of surface water and groundwater $[7,8]$.

Conventional physical- and chemical-based methods for sewage, such as oxidation ditch, SBR, A/O, $\mathrm{A}^{2} / \mathrm{O}$, ion exchange, and coagulation precipitation, require a combination of multiple reaction components and large energy inputs to realize nitrification and denitrification $[9,10]$. These processes generally entail high investment, complex operations and operational costs, and they can easily lead to secondary pollution $[10,11]$. Considering the capacity to remove high concentrations of nutrients, in particular, nitrogen and phosphorus [5,12-14], microalgae have been utilized to explore an economically sustainable and environmentally friendly approach to effectively treat wastewater from different sources $[15,16]$. 
The algae-based approach has been widely used in wastewater treatment [17]. Sufficient quantities of various nutrients in domestic sewage, such as $\mathrm{N}, \mathrm{P}$, and carbonaceous substances, are used to support the growth of algae and thus lower the concentrations of these compounds in water [18-20]. The primary advantage of integrating microalgae is their fast growth and strong adaptability in wastewater [21]. Both inorganic and organic nitrogen present in ammonia, nitrite, and nitrates can be utilized by microalgae in wastewater $[2,22,23]$. All microalgae have potential to remove or transform heavy metals and other contaminants from wastewater $[19,24-26]$. Secondly, large amounts of biomass are simultaneously produced as an alternative to the production of third generation biofuels [14,27-29], and as value-added ingredients $[2,30,31]$. Furthermore, microalgae also represent a promising method for $\mathrm{CO}_{2}$ fixation and $\mathrm{O}_{2}$ generation by photosynthesis to achieve carbon emission reductions [32-34]. Chlorella vulgaris, Tetradesmus obliquus, Parachlorella kessleri, Hydrodictyon sp., and Scenedesmus quadricauda have shown good application effects in pig wastewater [35-37], fishery wastewater [38,39], brewery wastewater [40], and as a secondary effluent of sewage plants [41,42]. Therefore, studies should be carried out to determine the effectiveness of a broad variety of algae species, which is of great value to microalgae usage for the treatment of wastewater from different sources.

The aim of this study is to analyze and discuss current trends in the use of microalgae biotechnology for the bioremediation of artificial domestic sewage. Specifically, the objectives are to evaluate the growth and consumption of COD, nitrogen, and phosphorus from simulated domestic wastewater by five commonly used green algal species: $C$. vulgaris, T. obliquus, P. kessleri, Hydrodictyon sp., and S. quadricauda. Microalgae species with the highest efficiency in nutrient removal and good growth are identified. The results of this study will aid the future use of microalgae-based biological methods for domestic wastewater treatment.

\section{Materials and Methods}

\subsection{Microalgae Species and Pre-Culture Conditions}

C. vulgaris (FACHB-8), T. obliquus (FACHB-416), P. kessleri (FACHB-729), Hydrodictyon sp. (FACHB-735), and S. quadricauda (FACHB-1297) were obtained from the Culture Collection of Algae, Institute of Hydrobiology, Chinese Academy of Sciences (FACHB-collection, Wuhan, China). Before the experiment, the algae were pre-cultivated with a BG11 medium in flasks under a $12 \mathrm{~h}: 12 \mathrm{~h}$ light/dark cycle under an incident light intensity of 2000 lux. The temperature of the culture room was maintained at $25^{\circ} \mathrm{C}$.

\subsection{Synthetic Wastewater}

Synthetic wastewater was used to formulate simulated domestic wastewater. The composition and concentration of trace elements in the synthetic wastewater were consistent with those in Blue-Green Medium (BG11). The composition of the synthetic wastewater was as follows (mg L ${ }^{-1}$ ): glucose 400, $\mathrm{NH}_{4} \mathrm{SO}_{4} 189, \mathrm{NaNO}_{3} 243, \mathrm{KH}_{2} \mathrm{PO}_{4} 43.90, \mathrm{NaHCO}_{3}$ $100, \mathrm{NaCl} 64, \mathrm{MgSO}_{4} \cdot 7 \mathrm{H}_{2} \mathrm{O} 185, \mathrm{FeSO}_{4} \cdot 7 \mathrm{H}_{2} \mathrm{O} 9.10, \mathrm{CaCl}_{2} 25, \mathrm{H}_{3} \mathrm{BO}_{3} 2.86, \mathrm{CuSO}_{4} \cdot 5 \mathrm{H}_{2} \mathrm{O}$ 0.08 , and $\mathrm{CoCl}_{2} \cdot 6 \mathrm{H}_{2} \mathrm{O} 0.05$. The water quality indexes of synthetic domestic sewage were measured according to the Chinese state standard testing methods (Administration, 2010). The initial $\mathrm{pH}$ of synthetic wastewater was approximately 7.5. Before the experiment, the synthetic wastewater was sterilized by ultraviolet light on a single-person, single-sided horizontal purification workbench (SW-CJ-1G, Suzhou, China) for $30 \mathrm{~min}$.

\subsection{Microalgal Batch Cultivation and Experimental Set-Up}

All five microalgae growing in the BG11 medium were collected via centrifugation at $6000 \mathrm{rpm}$ for $5 \mathrm{~min}$ when they were in the logarithmic growth phase. Pellets were washed with deionized water and centrifuged a second time at $6000 \mathrm{rpm}$ for $5 \mathrm{~min}$. Pellets were then suspended in a small volume of wastewater and subsequently inoculated to $250 \mathrm{~mL}$ flasks containing $200 \mathrm{~mL}$ of wastewater. 


\subsection{Analytical Methods}

\subsubsection{Determination of Microalgal Growth}

For microalgal growth determination, biomass production was measured as the dry algal cell weight (DW) concentration, according to the Chinese state standard monitoring method (Monitoring Method of Water and Wastewater, 2002) [43]. The algae liquid was shaken manually; $10 \mathrm{~mL}$ of the algae liquid was taken each time; and the cells were collected by filtration with a $0.45 \mu \mathrm{m}$ cellulose acetate membrane to determine the microalgae biomass. Then, the blank cellulose acetate membrane and the cellulose acetate membrane with algae cells were dried at $105{ }^{\circ} \mathrm{C}$ for $24 \mathrm{~h}$, and the dry weights were respectively weighed.

The microalgal concentration $\left(\mathrm{mg} \mathrm{L}^{-1}\right)$ was calculated according to the following Formula (1):

$$
\text { Microalgal concentration }=\left(\mathrm{DWt}_{\mathrm{i}}-\mathrm{DWt}_{0}\right) / \mathrm{V}
$$

where $\mathrm{DWt} \mathrm{t}_{\mathrm{i}}$ and $\mathrm{DWt} \mathrm{t}_{0}$ refer to the dry weight of filters with microalgal cells and dry weight of blank filters, respectively. $\mathrm{V}$ is the volume of microalgal culture.

The specific growth rate $(\mu)$ of microalgae was calculated according to the following Equation (2):

$$
\mu=\left(\operatorname{lnDWt}_{2}-\operatorname{lnDWt_{1}}\right) /\left(\mathrm{t}_{2}-\mathrm{t}_{1}\right)
$$

where $\mathrm{DWt}_{2}$ and $\mathrm{DWt}_{1}$ refer to the dry weight of microalgal biomass per unit volume $\left(\mathrm{mg} \mathrm{L}^{-1}\right)$ at time $\mathrm{t}_{2}$ and $\mathrm{t}_{1}$, respectively.

\subsubsection{Determination of Water Quality}

For each experiment, $10 \mathrm{~mL}$ of the algae mixture was centrifuged at $6000 \mathrm{rpm}$ for $5 \mathrm{~min}$, and the supernatant was filtered through a $0.45 \mu \mathrm{m}$ cellulose acetate membrane. Approximately $8 \mathrm{~mL}$ of the filtered supernatant was collected. The filtered supernatant was then used to determine $\mathrm{COD}, \mathrm{NH}_{4}-\mathrm{N}, \mathrm{TN}$, and TP. $\mathrm{COD}, \mathrm{NH}_{4}-\mathrm{N}, \mathrm{TN}$, and TP were analyzed by the dichromate method, salicylic acid spectrophotometry, alkaline potassium persulfate digestion UV spectrophotometric method, and ammonium molybdate spectrophotometric method, respectively (Monitoring Method of Water and Wastewater, 2002) [43]. The $\mathrm{pH}$ of wastewater was measured using a portable multiparameter analyzer FE-28 (Shanghai Mettler Toledo Instruments Co., Ltd., Shanghai, China).

\subsubsection{Determination of Chlorophyll Fluorescence}

Chlorophyll fluorescence parameters were measured according to Markou et al. [44] using a portable PAM fluorometer AquaPen-C AP-C 100 (Photon Systems Instruments, Czech Republic). The rapid information provided by the fluorescence of living chlorophyll reflects the utilization and dissipation of excitation energy by the photosystem II (PSII). For each measurement, the cuvette was filled with $3 \mathrm{~mL}$ of the algae culture, and the cuvette was closed with a stopper. After $15 \mathrm{~min}$ of dark adaptation at room temperature, the values of $\mathrm{Fv} / \mathrm{Fo}$ and $\mathrm{Fv} / \mathrm{Fm}$ were automatically obtained via the PAM fluorometer using the OJIP test.

The chlorophyll fluorescence parameters were as follows:

F0: initial fluorescence (F50 $\mu \mathrm{s}$, fluorescence intensity at $50 \mu \mathrm{s})$. Refers to the fluorescence when all reaction centers of PSII are in a fully open state, and all non-photochemical processes are at a minimum under dark adaptation.

Fm: maximal fluorescence intensity. Refers to the fluorescence when all reaction centers of PSII are in a completely closed state (that is, no photochemical reaction is carried out) and all non-photochemical processes are at a minimum in the dark adaptation state.

Fv: maximal variable fluorescence (Fm-F0). Refers to the maximum variable fluorescence when all non-photochemical processes are at a minimum in the dark adaptation state.

Fv/Fo: potential activity of PSII. Although Fv/Fo is not a direct efficiency indicator, it is sensitive to changes in efficiency. 
Fv / Fm: maximum quantum yield of PSII photochemistry ((Fm - F0) $/ \mathrm{Fm}, 0<\mathrm{Fv} / \mathrm{Fm}<1)$. Reflects the quantum yield when all PSII reaction centers are in an open state.

\subsubsection{Statistical Analysis}

Measurements were expressed as mean \pm standard deviation from three independent experiments. Differences between means were determined using $t$-tests and one-way analysis of variance in SPSS25 software. A confidence level of $95 \%$ was used to assess significance; the $p$-value threshold for significance was 0.05 .

\section{Results and Discussion}

\subsection{Nutrient Removal and COD Decrease Efficiency of Five Green Microalgae Species in Artificial Domestic Sewage}

In this study, the efficacy of different microalgae species for the remediation of wastewater was evaluated based on $\mathrm{COD}$ decrease and $\mathrm{TP}, \mathrm{TN}$, and $\mathrm{NH}_{4}-\mathrm{N}$ removal rates. Figure 1 shows the pollutant removal profiles of the five algae cultivated in artificial domestic sewage. The COD of the original wastewater was approximately $395.00 \mathrm{mg} \mathrm{L}^{-1}$, and the original total phosphorus concentration was $11.23 \mathrm{mg} \mathrm{L}^{-1}$. The original ammonia concentration was approximately $47.22 \mathrm{mg} \mathrm{L}^{-1}$, and the original total nitrogen concentration was approximately $50.56 \mathrm{mg} \mathrm{L}^{-1}$. All microalgae were capable of removing nitrogen and phosphorus from artificial domestic sewage. The pollutant concentrations in all experiments decreased rapidly within $2 \mathrm{~d}$ of cultivation. The nutrient concentrations decreased slightly from the 2 nd to the 6 th day. During the last $4 \mathrm{~d}$ of cultivation, the pollutant concentrations did not change significantly (Figure 1). These five microalgae species differed in their ability to remove nitrogen and phosphorus. T. obliquus and P. kessleri removed more nitrogen and phosphorus in the first $4 \mathrm{~d}$ compared with the other three microalgae. T. obliquus achieved removal rates of $69.46 \%$ and $61.33 \%$ of ammonia nitrogen and total phosphorus in the first $4 \mathrm{~d}$, respectively (Table 1). T. obliquus and P. kessleri could remove $60.06 \%$ and $59.39 \%$ of total phosphorus, respectively. After $4 \mathrm{~d}$ of cultivation, T. obliquus and $P$. kessleri could reduce $73.42 \%$ and $75.95 \%$ of COD, respectively. These two microalgae could remove greater amounts of pollutants compared with the other three microalgae. After culture for $10 \mathrm{~d}$ until the end of the experiment, the removal rates of the different pollutants by Chlorella vulgaris, P. kessleri, T. obliquus, Hydrodictyon sp., and S. quadricauda in the simulated domestic wastewater were ammonia nitrogen: 72.15, 75.71, 78.76, 67.62, and $78.35 \%$; total nitrogen: $73.46,75.65,74.46,67.12$, and $77.50 \%$; and total phosphorus: $70.57,66.79,69.64,73.60$, and 75.33\%, respectively. Except Hydrodictyon sp., the remaining 4 species of microalgae can reduce COD by more than $80 \%$. (Table 1 ). The experimental results show that all microalgae species, except for Hydrodictyon sp., can effectively remove nutrients.

To date, extensive research has been conducted on the removal of nitrogen from sewage by microalgae. Sydney et al. [45] cultured C. vulgaris in synthetic sewage for nitrogen removal. After $14 \mathrm{~d}$ of cultivation, the nitrogen removal efficiency reached $73.77 \%$. A recent study showed that the nitrogen removal of $C$. vulgaris was greater than $98 \%$ after $25 \mathrm{~d}$ [46]. To enhance the removal efficiency of nitrogen and phosphorus, microalgae are often cultivated for longer periods in experiments. Obviously, the ability of microalgae to remove pollutants in sewage is reduced if the amount of sewage discharged is large. Microalgae tend to store excess phosphorus for growth and biosynthesis. Therefore, phosphorus is over-absorbed by microalgae in the early stages of growth $[19,30]$. The removal efficiency of ammonium and total nitrogen decreased with the growth of $P$. kessleri, which is consistent with the results of previous experiments showing that more rapid increases in biomass result in more rapid nitrogen removal and indicates that the removal of nitrogen stems from assimilation by the algae. However, during the cultivation process, the $\mathrm{pH}$ increased with cultivation time, which may lead to the volatilization of ammonia [47]. Simulating the imbalance of nitrogen/phosphorus in domestic wastewater may limit the removal process of assimilated nutrients. The different ratio of $\mathrm{N} / \mathrm{P}$ has an important 
impact on the removal effect of pollutants. According to research, the higher the ratio of $\mathrm{N} / \mathrm{P}$, the better the removal effect of nutrients. Research shows that when the ratio of N/P is 5 , the removal effect of nitrogen and phosphorus is relatively good $[48,49]$. Stumm's empirical formula for microalgae is $\mathrm{C}_{106} \mathrm{H}_{263} \mathrm{O}_{110} \mathrm{~N}_{16} \mathrm{P}$ (the ratio of nitrogen to phosphorus is 7.2:1), which also provides a reference for the ratio of nitrogen to phosphorus in sewage; however, the average composition of microalgae cells depends on the strain and growth conditions [20]. This also confirms the excessive absorption of nitrogen and phosphorus during microalgae cultivation.
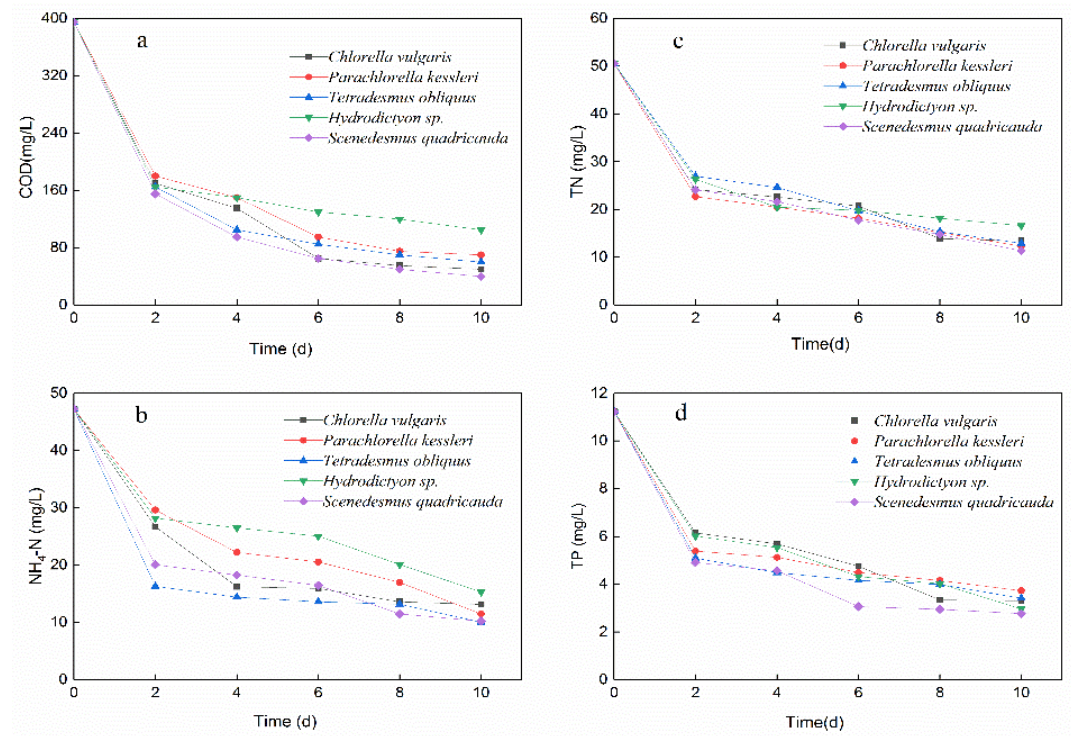

Figure 1. COD, ammonia nitrogen, total nitrogen, and total phosphorus removal of Chlorella vulgaris, Tetradesmus obliquus, Parachlorella kessleri, Hydrodictyon sp., and Scenedesmus quadricauda cultivated in the simulated domestic wastewater during 10 days of cultivation time. In the figure, (a-d) correspond to changes in the removal of COD, ammonia nitrogen, total nitrogen, and total phosphorus. All values are means \pm standard deviation of three independent experiments $(n=3)$.

Table 1. The percentage of COD, nitrogen, and phosphorus removal by five microalgae throughout the 10-day treatment period.

\begin{tabular}{ccccccc}
\hline $\begin{array}{c}\text { Water Quality } \\
\text { Parameters }\end{array}$ & $\begin{array}{c}\text { Cultivation } \\
\text { Time }\end{array}$ & $\begin{array}{c}\text { Chlorella } \\
\text { vulgaris }\end{array}$ & $\begin{array}{c}\text { Parachlorella } \\
\text { kessleri }\end{array}$ & $\begin{array}{c}\text { Tetradesmus } \\
\text { obliquus }\end{array}$ & $\begin{array}{c}\text { Hydrodictyon } \\
\text { sp. }\end{array}$ & $\begin{array}{c}\text { Scenedesmus } \\
\text { quadricauda }\end{array}$ \\
\hline COD & 2 & 56.962 & 54.430 & 58.228 & 58.228 & 60.759 \\
removal & 4 & 65.823 & 62.025 & 73.417 & 62.025 & 75.949 \\
$(\%)$ & 6 & 83.544 & 75.949 & 78.481 & 67.089 & 83.544 \\
& 8 & 86.076 & 81.013 & 82.278 & 69.620 & 87.342 \\
NH $_{4}-\mathrm{N}$ & 10 & 87.342 & 82.278 & 84.810 & 73.418 & 89.873 \\
Removal & 2 & 43.467 & 37.272 & 65.491 & 40.258 & 57.518 \\
$(\%)$ & 4 & 65.618 & 52.922 & 69.462 & 43.585 & 61.330 \\
& 6 & 66.306 & 56.501 & 71.198 & 46.929 & 65.121 \\
TN & 8 & 71.177 & 64.040 & 72.067 & 57.412 & 75.699 \\
Removal & 10 & 72.152 & 75.709 & 78.759 & 67.620 & 78.346 \\
$(\%)$ & 2 & 52.170 & 55.158 & 46.632 & 47.938 & 52.290 \\
& 4 & 55.257 & 59.460 & 51.340 & 59.460 & 57.156 \\
TP & 6 & 59.044 & 64.049 & 60.993 & 60.756 & 64.929 \\
Removal & 8 & 72.555 & 69.894 & 69.657 & 64.019 & 70.765 \\
$(\%)$ & 10 & 73.455 & 75.650 & 74.463 & 67.115 & 77.500 \\
& 2 & 45.236 & 52.004 & 54.675 & 46.394 & 56.322 \\
& 4 & 49.377 & 54.363 & 60.062 & 50.757 & 59.394 \\
\end{tabular}


In the simulated domestic wastewater, P. kessleri, S. quadricauda, and T. obliquus had a good nitrogen removal effect in the first $4 \mathrm{~d}$. S. quadricauda and T. obliquus showed strong potential activity during photosynthesis. S. quadricauda and T. obliquus had strong nitrogen removal activity compared with the three other microalgae, indicating that the nitrogen removal ability is species dependent [2]. This indicates that these two microalgae could be used for nitrogen removal when the amount of sewage discharge is large; they could also reduce the time needed to cultivate microalgae.

\subsection{Growth Profiles of Five Green Microalgae Species in Simulated Domestic Wastewater}

Five green microalgae species, C. vulgaris, T. obliquus, P. kessleri, Hydrodictyon sp., and $S$. quadricauda, were cultivated in artificial domestic wastewater. The growth curves of the five microalgae in artificial domestic sewage are shown in Figure 2a. All five microalgae could grow wastewater without a lag phase, which indicates that all these microalgae adapted well to artificial domestic sewage. The biomass concentrations of C. vulgaris, T. obliquus, P. kessleri, Hydrodictyon sp., and S. quadricauda significantly increased from approximately $100 \mathrm{mg} \mathrm{L}{ }^{-1}$ to $413.33,220.00,376.67,273.33$, and $213.33 \mathrm{mg} \mathrm{L}^{-1}$, respectively, after $3 \mathrm{~d}$ of cultivation (Figure $2 \mathrm{a}$ ). After $5 \mathrm{~d}$ of cultivation in simulated domestic wastewater, the biomass was in equilibrium. By the end of the cultivation, the biomass concentration of these five microalgae decreased to 206.67, 76.67, 106.67, 70.00, and $16.67 \mathrm{mg} \mathrm{L}^{-1}$, respectively (Figure $2 \mathrm{a}$ ). In the experiment, all five species of microalgae reached the logarithmic growth phase in the first $3 \mathrm{~d}$.
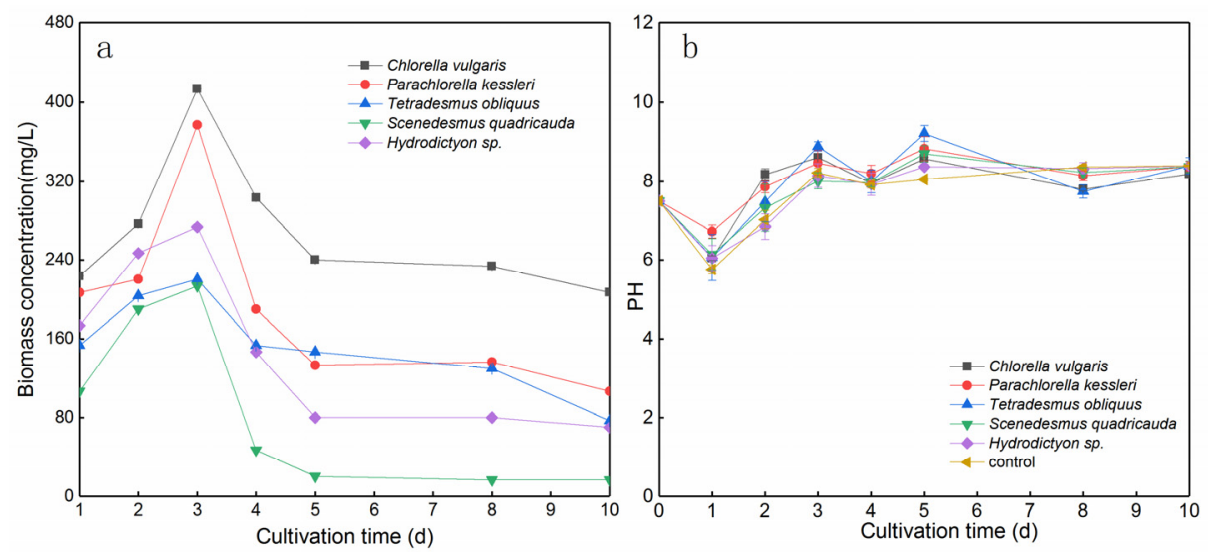

Figure 2. The biomass concentration (a) and $\mathrm{pH}(\mathbf{b})$ change of Chlorella vulgaris, Tetradesmus obliquus, Parachlorella kessleri, Hydrodictyon sp., and Scenedesmus quadricauda in the simulated domestic wastewater. All values are means \pm standard deviation of three independent experiments $(n=3)$.

The growth of microalgae requires sufficient amounts of nitrogen and phosphorus, and the addition of these elements in the absence of wastewater via fertilizer can significantly increase production costs [27]. Previous studies have shown that sewage is rich in nitrogen and phosphorus, and can thus provide an energy source for the growth of algae biomass. Consequently, microalgae can remove large amounts of nutrients, such as nitrogen and phosphorus [6]. Microalgae species vary in their degree of nitrogen and phosphorus utilization $[5,6]$. In this study, simulated domestic sewage was used as the nutrient source for the growth of microalgae, and the growth characteristics of five types of microalgae were studied. The maximum biomass concentration of these five microalgae cultivated in simulated domestic sewage ranged from $213.333 \mathrm{mg} \mathrm{L}^{-1}$ to $413.333 \mathrm{mg} \mathrm{L}^{-1}$ (Table 2). The highest biomass concentration of $C$. vulgaris in simulated domestic sewage is $413.333 \mathrm{mg} \mathrm{L}^{-1}$. The biomass concentration of $C$. vulgaris in this study is similar to that reported in previous studies $[13,50]$. The microalgae biomass of $P$. kessleri grows rapidly, reaching $376.667 \mathrm{mg} \mathrm{L}^{-1}$ in three days [51]. The biomass concentration of the remaining three microalgae exceeded $200 \mathrm{mg} \mathrm{L}^{-1}$ on the third day [52-54]. However, the biomass concentrations of the four microalgae T. obliquus, P. kessleri, Hydrodictyon sp., and S. quadricauda were lower compared 
with previous studies. These five microalgae could successfully adapt to and survive in simulated domestic sewage.

Table 2. Maximum biomass concentration and maximum specific growth rate of five microalgae cultivated in the simulated domestic sewage during 10 days of cultivation time. All values are means of three independent experiments $(n=3)$.

\begin{tabular}{|c|c|c|c|}
\hline Microalgal Strain & $\begin{array}{l}\text { Maximum Biomass } \\
\text { Concentration } \\
\left(\mathrm{mg} \mathrm{L}^{-1}\right)\end{array}$ & $\begin{array}{l}\text { Maximum Biomass } \\
\text { Concentration Time } \\
\text { (d) }\end{array}$ & $\begin{array}{c}\text { Maximum Specific } \\
\text { Growth Rate } \\
\left(\mu \mathrm{max}, \mathrm{d}^{-1}\right)\end{array}$ \\
\hline Chlorella vulgaris & $413.333 \pm 0.002^{a}$ & 3 & $0.401^{\mathrm{a}}$ \\
\hline Tetradesmus obliquus & $220.000 \pm 0.001^{b}$ & 3 & $0.282^{a}$ \\
\hline Parachlorella kessleri & $376.667 \pm 0.001^{\mathrm{a}}$ & 3 & $0.538^{b}$ \\
\hline Hydrodictyon sp. & $273.333 \pm 0.001^{b}$ & 3 & $0.353^{\mathrm{a}}$ \\
\hline $\begin{array}{l}\text { Scenedesmus } \\
\text { quadricauda }\end{array}$ & $213.333 \pm 0.000^{c}$ & 3 & $0.439^{a}$ \\
\hline
\end{tabular}

Note: Values are means \pm standard deviation, $n=3$. Different superscript letters indicate significant differences $(p<0.05)$ in values of maximum biomass concentration or maximum specific growth rate of each microalgal species cultivated in the simulated domestic wastewater.

The specific growth rate is an important factor reflecting the growth characteristics of algae that has become indispensable for studying the growth potential of microalgae. The specific growth rate of these five types of microalgae under simulated domestic wastewater conditions was analyzed [28], which indirectly reflects the growth status of different species of microalgae in simulated domestic wastewater (Table 2). The maximum specific growth rates of the five species of microalgae ranged from $0.282 \mathrm{~d}^{-1}$ to $0.577 \mathrm{~d}^{-1}(p<0.05)$, which was similar to or lower than values for the same algae species or genera in previous studies [50,55]. Five kinds of microalgae can adapt well to synthetic wastewater. Although the five species of microalgae were cultured and grown in the same simulated domestic wastewater, their biomass and specific growth rate varied, which reflected differences in their ability to adapt to the wastewater environment. This is consistent with the results of previous studies [49,56]. The maximum specific growth rate of $C$. vulgaris and P. kessleri is much higher than that of T. obliquus and Hydrodictyon sp. $(p<0.05)$, which indicates that the former two have higher growth potential in simulated domestic wastewater.

Changes in the $\mathrm{pH}$ in the process of artificial domestic sewage treatment are shown in Figure 2b. For all five microalgae species, the water was alkaline, and the $\mathrm{pH}$ changed little. The change in $\mathrm{pH}$ is mainly affected by the physiological activities of algae. The algae photosynthesize and absorb $\mathrm{CO}_{2}$, disrupting the acid-base balance in the sewage and increasing the $\mathrm{pH}$. The $\mathrm{CO}_{2}$ produced by the respiration of algae produces $\mathrm{H}^{+}$, which alters the balance between $\mathrm{CO}_{2}, \mathrm{HCO}_{3}{ }^{-}$, and $\mathrm{CO}_{3}{ }^{2-}$ in the water body and affects the $\mathrm{pH}$. Algae photosynthesis consumes $\mathrm{CO}_{2}$ at a much greater rate than the rate at which $\mathrm{CO}_{2}$ is produced by respiration, resulting in an increase in the $\mathrm{CO}_{3}{ }^{2-} / \mathrm{HCO}_{3}{ }^{-}$ratio and thus $\mathrm{pH}$. The increase in $\mathrm{pH}$ during the cultivation of microalgae confirms that the culture environment in domestic sewage is alkaline. The increased $\mathrm{pH}$ results in the deposition of calcium and phosphorus, which also leads to a reduction in the phosphorus concentration in domestic sewage [56].

\subsection{Chlorophyll Fluorescence of the Five Green Microalgae Species in Artificial Domestic Sewage}

The microalgae in this study contain chloroplasts, which can convert carbon dioxide and water into organic substances, such as sugars, through chloroplast photosynthesis and light energy, and store energy. Through the fluorescence properties of chlorophyll, it reflects the growth state and activity of microalgae. The growth potential of five microalgae in artificial domestic wastewater was determined by analyzing the chlorophyll fluorescence characteristics of microalgae cells. The Fv/Fo and Fv/Fm values of all five species of microalgae increased in the first 4 days and reached relatively stable values on the fourth day (Figure 3). After the 4th day, the Fv/Fo and Fv / Fm values of microalgae have been 
increasing slowly. Although there was a slight decrease thereafter, the $\mathrm{Fv} / \mathrm{Fo}$ and $\mathrm{Fv} / \mathrm{Fm}$ values remained relatively high. The $\mathrm{Fv} / \mathrm{Fm}$ value of all microalgae cells reached approximately 0.7 (Figure 3), which is similar to values previously reported for microalgae cultured in sewage $[27,57]$. The $\mathrm{Fv} / \mathrm{Fo}$ and $\mathrm{Fv} / \mathrm{Fm}$ values of $P$. kessleri and Hydrodictyon sp. were relatively low, and the $\mathrm{Fv} / \mathrm{Fo}$ and $\mathrm{Fv} / \mathrm{Fm}$ values of $C$. vulgaris, T. obliquus, and $S$. quadricauda were relatively high. The $\mathrm{Fv} / \mathrm{Fo}$ and $\mathrm{Fv} / \mathrm{Fm}$ values of these five microalgae increased in the first $2 \mathrm{~d}$; however, significant declines in the $\mathrm{Fv} / \mathrm{Fo}$ and $\mathrm{Fv} / \mathrm{Fm}$ values after $2 \mathrm{~d}$ were observed for Chlorella vulgaris, P. kessleri, and Hydrodictyon sp. Fv/Fo indicates the potential activity of PSII, and Fv/Fm is the maximum photochemical quantum yield under dark conditions. Therefore, $C$. vulgaris and P. kessleri cultivated in artificial domestic wastewater, which had higher Fv/Fo and Fv/Fm values, showed better growth and metabolic activity. As the growth of microalgae in sewage is species dependent, the selection of appropriate algae species is critically important for optimizing domestic sewage treatment [20].
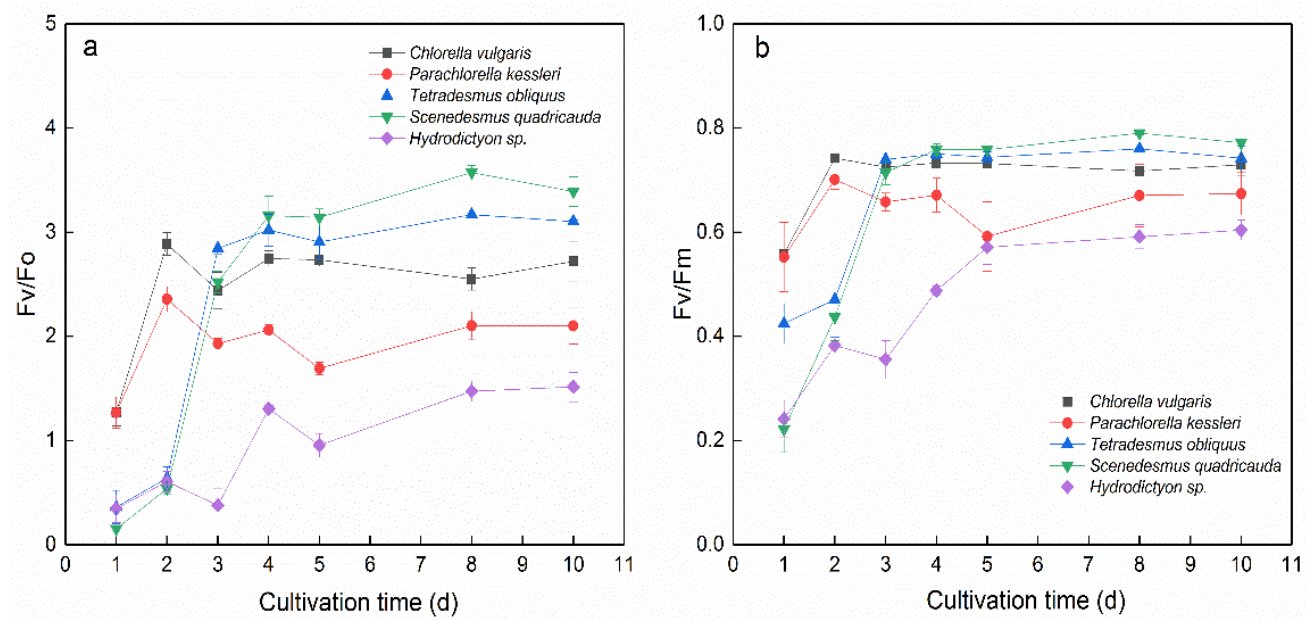

Figure 3. Fv/Fo (a) and Fv/Fm (b) of Chlorella vulgaris, Tetradesmus obliquus, Parachlorella kessleri, Hydrodictyon sp., and Scenedesmus quadricauda cultivated in the simulated domestic wastewater during 10 days of cultivation time. All values are means \pm standard deviation of three independent experiments $(n=3)$.

\section{Conclusions}

Five commonly used green algal species (C. vulgaris, P. kessleri, T. obliquus, Hydrodictyon sp., and S. quadricauda) could grow in simulated domestic wastewater. C. vulgaris and P. kessleri grew better compared to T. obliquus, Hydrodictyon sp., and S. quadricauda. The nutrient removal effects of $P$. kessleri and S. quadricauda from simulated domestic wastewater were high. Within 4 to $6 \mathrm{~d}$ of treatment, most of the nutrient elements were removed from the simulated domestic wastewater. Therefore, P. kessleri was superior to the other four microalgae in terms of its growth potential and pollutant removal effect, suggesting that it could be used for the removal of nutrients from domestic sewage.

Author Contributions: Conceptualization, L.J.; methodology, Q.G. and S.X.; investigation, S.X. and Q.G.; writing —original draft preparation, Q.G. and Y.G.; formal analysis, Q.G.; writing-review and editing, L.J.; validation, Q.G., Y.G. and Y.L.; data curation, Q.G. and Y.L.; project administration, L.J.; visualization, Q.G. and S.X.; supervision, L.J.; funding acquisition, L.J. All authors approved the final manuscript. All authors have read and agreed to the published version of the manuscript.

Funding: This study was funded by the National Natural Science Foundation of China, grant number 42177057; the grants from CAS Key Laboratory of Soil Environment and Pollution Remediation, Institute of Soil Science, Chinese Academy of Sciences (SEPR2020-03); and the Doctoral Scientific Research Foundation for Taiyuan University of Science and Technology, grant number 20202069.

Acknowledgments: The authors thank Na Li, Wenwen Li, Yu Gao, and other laboratory members for algal culture and technical assistance. 
Conflicts of Interest: The authors declare no conflict of interest.

\section{References}

1. Koop, S.H.; Leeuwen, C.J. The challenges of water, waste and climate change in cities. Environ. Dev. Sustain. 2017, 19, 385-418. [CrossRef]

2. Lv, J.P.; Wang, X.C.; Feng, J.; Liu, Q.; Nan, F.R.; Jiao, X.Y.; Xie, S.L. Comparison of growth characteristics and nitrogen removal capacity of five species of green algae. J. Appl. Phycol. 2019, 31, 409-421. [CrossRef]

3. Prosser, R.S.; Sibley, P.K. Human health risk assessment of pharmaceuticals and personal care products in plant tissue due to biosolids and manure amendments, and wastewater irrigation. Environ. Int. 2015, 75, 223-233. [CrossRef] [PubMed]

4. Mennaa, F.Z.; Arbib, Z.; Perales, J.A. Urban wastewater treatment by seven species of microalgae and an algal bloom: Biomass production, $\mathrm{N}$ and $\mathrm{P}$ removal kinetics and harvestability. Water Res. 2015, 83, 42-51. [CrossRef] [PubMed]

5. Li, K.; Liu, Q.; Fang, F.; Luo, R.H.; Lu, Q.; Zhou, W.G.; Huo, S.H.; Cheng, P.F.; Liu, J.Z.; Addy, M.; et al. Microalgae-based wastewater treatment for nutrients recovery: A review. Bioresour. Technol. 2019, 291, 121934. [CrossRef] [PubMed]

6. Samorì, G.; Samorì, C.; Guerrini, F.; Pistocchi, R. Growth and nitrogen removal capacity of Desmodesmus communis and of a natural microalgae consortium in a batch culture system in view of urban wastewater treatment: Part I. Water Res. 2013, 47, 791-801. [CrossRef] [PubMed]

7. Ghernaout, D.; Elboughdiri, N. Domestic Wastewater Treatment: Difficulties and Reasons, and Prospective Solutions-China as an Example. Open Access Libr. J. 2020, 7, 1-15. [CrossRef]

8. Eduardo, C.; Lúcia, C.M.; Paula, A.; Roberto, C.P. Evaluation of high rate ponds operational and design strategies for algal biomass production and domestic wastewater treatment. Sci. Total Environ. 2021, 791, 148362. [CrossRef]

9. Sun, S.P.; Nàcher, C.P.; Merkey, B.; Zhou, Q.; Xia, S.Q.; Yang, D.H.; Sun, J.H.; Smets, B.F. Effective biological nitrogen removal treatmentprocesses for domestic wastewaters with low C/N ratios: A review. Environ. Eng. Sci. 2010, 27, 111-126. [CrossRef]

10. Zanetti, L.; Frison, N.; Nota, E.; Tomizioli, M.; Bolzonella, D.; Fatone, F. Progress in real-time control applied to biological nitrogen removal from wastewater. A short-review. Desalination 2012, 286, 1-7. [CrossRef]

11. Arbib, Z.; Ruiz, J.; Álvarez-Díaz, P.; Garrido-Pérez, C.; Perales, J.A. Capability of different microalgae species for phytoremediation processes: Wastewater tertiary treatment, $\mathrm{CO}_{2}$ bio-fixation and low cost biofuels production. Water Res. 2014, 49, 465-474. [CrossRef] [PubMed]

12. Aslan, S.; Kapdan, I.K. Batch kinetics of nitrogen and phosphorus removal from synthetic wastewater by algae. Ecol. Eng. 2006, 28, 64-70. [CrossRef]

13. Zhu, L.D.; Wang, Z.M.; Shu, Q.; Takala, J.; Hiltunen, E.; Feng, P.Z.; Yuan, Z.H. Nutrient removal and biodiesel production by integration of freshwater algae cultivation with piggery wastewater treatment. Water Res. 2013, 47, 4294-4302. [CrossRef]

14. Luo, L.; He, H.J.; Yang, C.P.; When, S.; Zeng, G.M.; Wu, M.J.; Zhou, Z.L.; Lou, W. Nutrient removal and lipid production by Coelastrella sp. in anaerobically and aerobically treated swine wastewater. Bioresour. Technol. 2016, 216, 135-141. [CrossRef] [PubMed]

15. Ahmed, S.; Ibrahim, M.; Ahmad, F.; Rana, H.A.; Rao, T.; Anwar, W.; Younus, M.; Ahmad, W.; Farooqi, S.H.; Aftab, A.; et al. Microbial risk assessment andantimicrobial resistance. In Antibiotics and Antimicrobial Resistance Genes in the Environment: Volume 1 in the Advances in Environmental Pollution Research Series; Elsevier: Amsterdam, The Netherlands, 2020; pp. 313-330. [CrossRef]

16. Ahmed, S.F.; Mofijur, M.; Samiha, N.; Tasnim, C.A.; Nazifa, R.; Alhaz, U.M.; Abrar, I.; Mahlia, T.M.; Chyuan, O.H.; Yi, C.W.; et al. Recent developments in physical, biological, chemical, and hybrid treatment techniques for removing emerging contaminants from wastewater. J. Hazard. Mater. 2021, 416, 125912. [CrossRef] [PubMed]

17. Lv, J.P.; Liu, G.J.; Feng, J.; Liu, Q.; Nan, F.R.; Liu, X.D.; Xie, S.L. Harvesting biomass of an oil-rich microalga Parachlorella kessleri TY02 by ferric chloride: Effects on harvesting efficiency, lipid production and municipal wastewater treatment. J. Environ. Manag. 2020, 273, 111128. [CrossRef] [PubMed]

18. Mohsenpour, S.F.; Hennige, S.; Willoughby, N.; Adeloye, A.; Gutierrez, T. Integrating micro-algae into wastewater treatment: A review. Sci. Total Environ. 2021, 752, 142168. [CrossRef]

19. Zhou, W.Z.; Li, Y.T.; Gao, Y.Z.; Zhao, H.X. Nutrients removal and recovery from saline wastewater by Spirulina platensis. Bioresour. Technol. 2017, 245, 10-17. [CrossRef] [PubMed]

20. Li, X.; Hu, H.Y.; Gan, K.; Sun, Y.X. Effects of different nitrogen and phosphorus concentrations on the growth, nutrient uptake, and lipid accumulation of a freshwater microalga Scenedesmus sp. Bioresour. Technol. 2010, 101, 5494-5500. [CrossRef]

21. Salama, E.S.; Kurade, M.B.; Abou-Shanab, R.A.; El-Dalatony, M.M.; Yang, I.S.; Min, B.; Jeon, B.H. Recent progress in microalgal biomass production coupled with wastewater treatment for biofuel generation. Renew. Sustain. Energy Rev. 2017, 79, 1189-1211. [CrossRef]

22. Ross, M.E.; Davis, K.; McColl, R.; Stanley, M.S.; Day, J.G.; Semiao, A.J. Nitrogen uptake by the macro-algae cladophora coelothrix and cladophora parriaudii: Influence on growth, nitrogen preference and biochemical composition. Algal Res. 2018, 30, 1-10. [CrossRef]

23. Forruque, A.S.; Mofijur, M.; Ahmed, P.T.; Nafisa, I.; Kusumo, F.; Abrar, I.; Giang, L.V.; Anjum, B.I.; Yunus, K.T.; Chyuan, O.H. Progress and challenges of contaminate removal from wastewater using microalgae biomass. Chemosphere 2021, 286, 131656. [CrossRef] 
24. Ji, L.; Xie, S.L.; Feng, J.; Li, Y.H.; Chen, L. Heavy metal uptake capacities by the common freshwatergreen alga Cladophora fracta. J. Appl. Phycol. 2012, 24, 979-983. [CrossRef]

25. Escapa, C.; Coimbra, R.N.; Neuparth, T.; Torres, T.; Santos, M.M.; Otero, M. Acetaminophen removal from water by microalgae and effluent toxicity assessment by the zebrafish embryo bioassay. Water 2019, 11, 1929. [CrossRef]

26. Nguyen, H.T.; Yoon, Y.; Ngo, H.H.; Jang, A. The application of microalgae in removing organic micropollutants in wastewater. Crit. Rev. Environ. Sci. Technol. 2020, 51, 1-34. [CrossRef]

27. Christenson, L.; Sims, R. Production and harvesting of microalgae for wastewater treatment, biofuels, and bioproducts. Biotechnol. Adv. 2011, 29, 686-702. [CrossRef]

28. Zhao, Y.J.; Ge, Z.G.; Lui, H.; Sun, S.Q. Ability of different microalgae species in synthetic high-strength wastewater treatment and potential lipid production. J. Chem. Technol. Biotechnol. 2016, 91, 2888-2895. [CrossRef]

29. Gao, Y.F.; Lv, J.P.; Feng, J.; Liu, Q.; Xie, S.L. Morphology, phylogeny and lipid components of an oil-rich microalgal strain. J. Appl. Bot. Food Qual. 2017, 90, 298-305. [CrossRef]

30. Zhu, S.N.; Wang, Y.J.; Xu, J.; Shang, C.H.; Wang, Z.G.; Xu, J.L.; Yuan, Z.H. Luxury uptake of phosphorus changes the accumulation of starch and lipid in Chlorella sp. under nitrogen depletion. Bioresour. Technol. 2015, 198, 165-171. [CrossRef]

31. Rizwan, M.; Mujtaba, G.; Memon, S.A.; Lee, K.; Rashid, N. Exploring the potential of microalgae for new biotechnology applications and beyond: A review. Renew. Sustain. Energy Rev. 2018, 92, 394-404. [CrossRef]

32. Almomani, F.A. Assessment and modeling of microalgae growth considering the effects $\mathrm{OF} \mathrm{CO}_{2}$, nutrients, dissolved organic carbon and solar irradiation. J. Environ. Manag. 2019, 247, 738-748. [CrossRef] [PubMed]

33. Shahid, A.; Malik, S.; Zhu, H.; Xu, J.; Nawaz, M.Z.; Nawaz, S.; Asraful Alam, M.; Mehmood, M.A. Cultivating microalgae in wastewater for biomass production, pollutant removal, and atmospheric carbon mitigation; a review. Sci. Total Environ. 2020, 704, 135303. [CrossRef] [PubMed]

34. Song, C.F.; Liu, Q.L.; Qi, Y.; Chen, G.Y.; Song, Y.J.; Kansha, Y.; Kitamura, Y. Absorption-microalgae hybrid $\mathrm{CO}_{2}$ capture and biotransformation strategy-A review. Int. J. Greenh. Gas Control 2019, 88, 109-117. [CrossRef]

35. Kwon, G.; Nam, J.H.; Kim, D.M.; Song, C.; Jahng, D. Growth and nutrient removal of Chlorella vulgaris in ammonia-reduced raw and anaerobically-digested piggery wastewaters. Environ. Eng. Res. 2019, 25, 135-146. [CrossRef]

36. Guo, G.Y.; Guan, J.; Sun, S.Q.; Liu, J.; Zhao, Y.J. Nutrient and heavy metal removal from piggery wastewater and $\mathrm{CH}_{4}$ enrichment in biogas based on microalgae cultivation technology under different initial inoculum concentration. Water Environ. Res. 2020, 92, 922-933. [CrossRef]

37. Alice, F.; Lusine, M.; Sofia, C.; Belina, R.; Daniel, F.; Gayane, A.; Luisa, G. Biostimulant and biopesticide potential of microalgae growing in piggery wastewater. Environ. Adv. 2021, 4, 100062. [CrossRef]

38. Liu, Y.; Lv, J.P.; Feng, J.; Liu, Q.; Nan, F.R.; Xie, S.L. Treatment of real aquaculture wastewater from a fishery utilizing phytoremediation with microalgae. J. Chem. Technol. Biotechnol. 2019, 94, 900-910. [CrossRef]

39. García-Martínez, J.B.; Urbina-Suarez, N.A.; Zuorro, A.; Barajas-Solano, A.F.; Kafarov, V. Fisheries wastewater as a sustainable media for the production of algae-based products. Chem. Eng. Trans. 2019, 76, 1339-1344. [CrossRef]

40. Mata, T.M.; Melo, A.C.; Simões, M.; Caetano, N.S. Parametric study of a brewery effluent treatment by microalgae Scenedesmus obliquus. Bioresour. Technol. 2012, 107, 151-158. [CrossRef] [PubMed]

41. Zhang, B.; Meng, F.P.; Cui, H.W.; Dou, X.; Du, S.H.; Peng, X.L. Microalgal Cultivation in Secondary Effluents: Enhancement of Algal Biomass, Nutrient Removal, and Lipid Productivity. J. Ocean Univ. China 2020, 19, 1461-1470. [CrossRef]

42. Min, K.J.; Oh, D.Y.; Park, K.Y. Pilot-scale cultivation of water-net in secondary effluent using an open pond raceway for nurient removal and bioethanol production. Chemosphere 2021, 277, 130129. [CrossRef]

43. State Environmental Protection Administration. Water and Wastewater Monitoring Analysis Method; China Environment Science Press: Beijing, China, 2002.

44. Markou, G.; Georgakakis, D. Cultivation of filamentous cyanobacteria (blue-green algae) in agro-industrial wastes and wastewaters: A review. Appl. Energy 2011, 88, 3389-3401. [CrossRef]

45. Sydney, E.B.; Da Silva, T.E.; Tokarski, A.; Novak, A.C.; De Carvalho, J.C.; Woiciecohwski, A.L.; Larroche, C.; Soccol, C.R. Screening of microalgae with potential for biodiesel production and nutrient removal from treated domestic sewage. Appl. Energy 2011, 88, 3291-3294. [CrossRef]

46. Koutra, E.; Grammatikopoulos, G.; Kornaros, M. Selection of microalgae intended for valorization of digestate from agro-waste mixtures. Waste Manag. 2018, 73, 123-129. [CrossRef] [PubMed]

47. Acuña-Alonso, C.; Lorenzo, O.; Álvarez, X.; Cancela, Á.; Valero, E.; Sánchez, Á. Influence of Microcystis sp. and freshwater algae on $\mathrm{pH}$ : Changes in their growth associated with sediment. Environ. Pollut. 2020, 263 Pt B, 114435. [CrossRef]

48. Rachel, O.; Mark, G.; Richard, M. The effects of Parachlorella kessleri cultivation on brewery wastewater. Water Sci. Technol. 2016, 73, 1401-1408. [CrossRef]

49. Wong, Y.K.; Yung, K.K.; Tsang, Y.F.; Xia, Y.; Wang, L.; Ho, K.C. Scenedesmus quadricauda for Nutrient Removal and Lipid Production in Wastewater. Water Environ. Res. 2015, 87, 2037-2044. [CrossRef]

50. Nayak, M.; Karemore, A.; Sen, R. Performance evaluation of microalgae for concomitant wastewater bioremediation, $\mathrm{CO}_{2}$ biofixation and lipid biosynthesis for biodiesel application. Algal Res. 2016, 16, 216-223. [CrossRef]

51. Figler, A.; B-Béres, V.; Dobronoki, D.; Márton, K.; Nagy, S.A.; Bácsi, I. Salt tolerance and desalination abilities of nine common green algae isolates. Water 2019, 11, 2527. [CrossRef] 
52. Figler, A.; Márton, K.; B-Béres, V.; Bácsi, I. Effects of nutrient content and nitrogen to phosphorous ratio on the growth, nutrient removal and desalination properties of the green alga Coelastrum morus on a laboratory scale. Energies 2021, 14, 2112. [CrossRef]

53. Fan, H.H.; Wang, K.; Wang, C.; Yu, F.Y.; He, X.X.; Ma, J.; Li, X.T. A comparative study on growth characters and nutrients removal from wastewater by two microalgae under optimized light regimes. Environ. Technol. Innov. 2020, 19, 100849. [CrossRef]

54. Wang, L.; Min, M.; Li, Y.C.; Chen, P.; Chen, Y.F.; Liu, Y.H.; Wang, Y.K.; Ruan, R. Cultivation of green algae Chlorella sp. in different wastewaters from municipal wastewater treatment plant. Appl. Biochem. Biotechnol. 2010, 162, 1174-1186. [CrossRef] [PubMed]

55. Zhao, Y.J.; Sun, S.Q.; Hu, C.W.; Zhang, H.; Xu, J.; Ping, L.F. Performance of three microalgal strains in biogas slurry purification and biogas upgrade in response to various mixed light-emitting diode light wavelengths. Bioresour. Technol. 2015, 187, 338-345. [CrossRef] [PubMed]

56. Yang, J.W.; Tang, H.X.; Zhang, X.X.; Zhu, X.X.; Huang, Y.; Yang, Z. High temperature and pH favor Microcystis aeruginosa to outcompete Scenedesmus obliquus. Environ. Sci. Pollut. Res. Int. 2018, 25, 4794-4802. [CrossRef] [PubMed]

57. Ma, S.S.; Yu, Y.L.; Cui, H.; Li, J.; Feng, Y.J. Utilization of domestic wastewater as a water source of Tetradesmus obliquus PF3 for the biological removal of nitric oxide. Environ. Pollut. 2020, 26, 114243. [CrossRef] [PubMed] 